\title{
V. CONCLUSION
}

It is the central contention of this study that the comedy form balances between recognition and disbelief; oscillates between reality and artificiality. It is artificlal in its dogged adherence to conventions, some of which have persisted for over 2,000 years, and are recognised as such by even the most undiscriminating spectator. The comedy demands at the same time a large component of recognisable reality; it is most often firmly founded in the society of its spectators. The social component offers the form its critical possibilities, which are most frequently executed by the aggressive satire. The social criticlsm of satire functions, however, in a relatively uncomplicated manner: Institutions, persons or political groups are examined for their shortcomings and held up for punishment by derisive laughter. With the exception of Rund um den KongreB the satirical elements in Horváth's comedies are rare. His dramaturgical method eschews direct attack in favour of a more complex process of disturbing the conscious and unconscious expectations of the spectator. By contrasting the less than Ideal state of the spectators' own world with the artificial conventions of comedy, where the restoration of harmony is either absent or only outwardly enforced because the conventions demand it, the form or genre itself is laid bare and the spectator is brought to a new critical perspective by being confronted with the discrepancy between expectation and fulfilment.

Horváth's unceasing experimentation with the comedy form and its many genres manifests itself in two ways. There are elements, common to all the comic genres, which undergo substantial changes and reversals of their normal function in comedy; and certain genres within the form display characterlstics peculiar to themselves. This study has traced Horváth's development as closely as possible in a chronological order; rigid grouping under genre or motif, it was decided, would too often obfuscate the central intention of each of the plays, most of which constitute relatively uncharted territory for Horváth scholarship. This method was not adopted for the Volksstücke written between 1929 and 1932 which comprise the core of his oeuvre and have attracted enough critical attention to assume familiarity with the works. In the case of these four plays, with their obvious thematic and formal links, an examination of particularly important motifs and conventions of the Volksstiuck was undertaken.

The Volksstück itself has a debatable place in the comedy form. Although a number of serious Volksstuicke can be found in the work of Anzengruber and. Thoma, a survey of the critical reaction to plays possessing this generic designation revealed a 
predominantly comedy expectation associated with it. This is due in no small measure to just such writers as Anzengruber and Thoma. The connotations of comedy and Volksstïck go back even further to the plays of Nestroy and Ralmund. However Horváth was more probably reacting against the conventions and elements of the rural, Volksstick of Anzengruber and Schönherr which had strong reactionary connotations and assoclations within the conservative Heimatkunst movement. Horváth's own statements criticising the aggressive right-wing groups indicate that he saw his Volksstick having a definite political and social purpose which could only be granted to a genre reacting against a contemporary notion, but which would have little value in criticising an extinct form of theatre such as the Viennese Popular Comedy. The dramaturgical method consists of taking certain elements of the genre, often connected with the rural milieu, such as the 'Volksfest' and the town/country contrast, and reversing the expectations assoclated with them. Instead of providing the spectacle of peasant folk practising celebrations with ritual significance, the petite-bourgeolsie is depicted at large commerclalised adaptations of such festivals, giving free reign to 1 ts instinctual drives in a mixture of unleashed eros and cruelty which oversteps the bounds of comic entertainment. Similarly the town and country conflict, a favorite convention of comedy which can be traced back to Aristophanes's Megarian peasants, and a recurrent theme in the rural Volksstick, is reversed to demonstrate a deldealised rural milieu. The idyllic unspollt country-side, perhaps the cornerstone of the Helmatkunst movement, is refashioned by Horváth into a place of horror and even death. His characters' connection to the land is characterised by estrangement. It takes the form of land purchase (the Stadtrat in Italienische Nacht), Sunday picnics in the Vienna Woods or excursions into the country-side by automobile resulting in sexual exploitation and loss of employment (Glaube Liebe Hoffnung). The only land-dwellers found in Geschichten aus dem Wiener Wald are in fact state employees, administering an old castle ruin. It is here too, in the Wachau, that the murder of Marlanne's child is perpetrated by the grandmother, possibly the most horrific act in the whole of Horváth's oeuvre.

Horváth's first performed play, the Volksstiuck Die Bergbahn, was dealt with separately. Not only did the author himself term It a "skizzenhaften Versuch" but it reveals important differences compared to the later Volksstucke. Nevertheless it manifests aims similar to those of the latter works. It was concelved as a counterversion to the trivial and Ideologically suspect 'Helmatstuick'. The reversal of expectations is achieved by depicting proletarian and politiclsed alpine dramatis personae, completely estranged from any trivialised notion of an intact 
rural environment. There is no trace of an idylilc 'Alm' or innocent 'Sennerinnen', Instead the harsh terrain forms the background for an undertaking where the exploitative and ruthless ethics of capitalism prevail, hitherto the preserve of the urban literature of Naturalism, the very movement against which Heimatkunst was reacting.

Those works possessing the subtitle 'Komödie' or 'Lustsplel', (whereby no special distinction was made between the two) cannot be easily incorporated into a unified group of works. First, these plays include both the first and last of his comedies (Zur schönen Aussicht and Pompeji) and consequently some type of development and modification in Horváth's attitude towards the form 1.s to be expected. Although all the works considered here have been subsumed under the comedy form, the 'Komödie' itself reveals a speciflc genre in the 'Konversationkomödie', the comedy of manners. It revolves around domestic concerns, chiefly money, and utilises witty dialogue and the comedy of situation. It was the dominant genre of the bourgeolsie of the 19th century and retained its dominance of the German stage during the Welmar Republic. By using this genre a wide audience could be guaranteed. Two plays could be classified under this term: Zur schönen Aussicht and Mit dem Kopf durch die Wand. The former represents Horváth's $\overline{\text { most }} \overline{\text { detalled }} \overline{\text { and }}$ effective reversal of this genre. Whereas the power of money has traditionally dictated the central concerns of the domestic comedy as far back as Plautus, in Zur schönen Aussicht the normal arrangement is turned upside down and replaced by the bizarre spectacle of the aging spinster Ada conducting a ménage á quatre. Inheritance, determined chlefly by patriarchical succession in the European comedy, is dictated by women; aristocrats abandon their social roles and behave like servants, while the servants are not in fact servants but are only impersonating them. The moral world of the comedy is topsy-turvy: even the usually comic play-within-a-play convention is utilised to decelve and humiliate rather than to enlighten and clarify.

Mit dem Kopf durch die Wand is also concerned with deception, Intrigue and impersonation, and again an aristocrat features whose raison d'être is a guilt complex based on the Illusion of having been responsible for the death of the mysterious Inconnue de la Seine. Otherwise the play exhausts itself in parody and self-consclous cleverness. It is related thematically to Horváth's perhaps darkest comedy: Die Unbekannte aus der Selne. The latter closely resembles the milieu of the "Stille StraBe" in Geschichten aus dem Wiener Wald, but its themes of murder and suicide blended with a touch of neoromantic mysticism remove it from the recognisable reality of the Volksstiuck. Together with Glaube Liebe Hoffnung, it incorporates 
most explicitly potentialiy tragic situations and motifs, and by exploring the kitsch-ridden consciousness of the characters, demonstrates in the pseudo-idyllic epilogue the impossibility of tragedy in the modern world of the petite-bourgeoisie.

The other main genre Horváth returns to is the 'Posse'. His first attempt, Rund um den KongreB, derives its genealogy from the contemporary post-Dadaist grotesque satire of Brecht, Ivan Goll, George Grosz and to the intellectual farce of Robert Musil. The later 'Posse mit Gesang' Hin und Her (1934) belongs without doubt to the tradition of the Viennese Popular Comedy and its assorted genres such as the 'Zaubermärchen' and the 'Märchenposse'. The term 'Märchen' given to Himmelwärts (1934) relates also to this baroque Austrian theatre and dramatic tradition.

Although the different genres require particular critical methods for their conventions, certain themes recur throughout Horvath's whole comedy oeuvre. Role-playing assumes one of the key functions in Horváth's comedies. In various manifestations it can be considered in fact one of the characteristic features of the comedy form. Role-playing in Horváth's drama encompasses traditional impersonation as well as the modern notion of identity crisis and social roles. The comedy form with this tradition of impersonation and scenic role-playing is singularly well equipped to convey the modern malaise of incompatibility with social roles which has developed into a major theme in modern literature. All the male characters in Zur schönen Aussloht have assumed another role, for them a less sultable social role. Characters such as Marianne, Karoline, and Elisabeth all display a deslre to rebel agalnst their social roles; Havlicek is dented a role in soclety and even his very existence is cast in doubt through his status as a stateless person, which throws up the interesting question of the relationship between Individual and state and the extent to which selfhood is determined by the state. In Himmelwärts Luise assumes the long-desired role of opera diva and basks in fame and acclaim; however, the diabolical power behind it finally plunges her into a severe crisis caused by the compromise of values. In Ein Dorf ohne Männer the convention is led ad absurdum with continual impersonation and again it goes deeper, when Matthias doubts his own intrinsic personal qualities and expresses the difficulty of distinguishing genuine response to himself, independent of his role as king. In Pompej1 the antique comedy convention of using masks is taken literally by Horváth to demonstrate in visual terms the discrepancy between social role and self. 
The distinguishing intention and expectation of the comedy form is the underlying movement to a better state of affairs than that depicted, or its utopian impulse to use Arntzen's and Hinck's term. Nowhere can this constituent element of the comedy be better examined than in the tradition of the happy ending. Horváth's comedies can be divided into two groups, those that end with a reconciliation in the form of a marriage or new relationship; and those that experience disharmony, or even death. In both cases the utopian possibility is either manifestly absent or supplied with an ironical twist that leaves no doubt as to the bleak future of the relationships and the moral state of the world. The expectations relating to this convention can be disappointed in a variety of ways. A happy ending can be blatantly manufactured as in Rund um den Kongres where the expectations relating to comedy, and to the 'Posse' in particular, are consciously invoked. The action of the play itself clearly precludes a harmonious ending but Horváth addresses the desires of the audience by having a spectator demand just such a reconciliation, regardless of the logic of the play. In a play such as Zur schönen Aussicht the harmony is in fact restored precisely by not ending in the marriage of comedy. This ending is itself disharmonious, at least within the ideology of the domestic comedy, which tends to insist on the restoration of the social status. Christine's 'escape' then is subversive by suggesting that the only way of attaining to a better world is outside the conventions of comedy and therefore beyond the social norm.

Horváth's later comedies were concelved with a different intention. Figaro läBt sich schelden, Ein Dorf ohne Männer and Pompe j1 all adapt Iiterary models and are situated in 'history', whereby Horváth's depiction of history is scarcely concemed with factual accuracy and is sprinkled with anachronisms wich reestablish the plays' connection with the contemporary world. The obvious debt to the sources functions to highlight these comedies' place in a literary tradition. In contrast to the general tendency of Horváth scholarship to stress the soclal-critical component, this consclous acknowledgement of the comedy tradition stresses precisely the artificlality of the comedy worlds deplcted in these later plays. Consequently, the harmonious solutions they may offer are only intended as an acknowledgement of the formal requirements of the comedy, rather than as a permanent resolution of the problems depicted.

What then is Horváth's contribution to modern comedy? Although he can be loosely grouped with a number of dramatists such as Musil and Brecht who demonstrated a similar interest in critically rehabilitating comedy genres, Horváth is the only dramatist of this perlod who concentrated almost exclusively on 
the comedy form as the dramatic form of the modern age. Not only is it the form with mass appeal, but the comedy reveals itself to be the more adaptable vehicle for deploting the modern world and the consciousness of contemporary man. This study has argued that Horváth's dramaturgical method utilises a subtle process of subverting the expectation of the spectator's consclousness; the enticement of uncomplicated entertainment is offered by a variety of generic designations. The gap between expectation and fulfilment which opens up should be filled by the spectator himself and in so doing activates a critical perspective which so often lies dormant and passive. That this method is still highly effective was demonstrated by the headlines from the Bildzeltung on the occasion of a production of Geschichten aus dem Wiener Wald in West Berlin in 1967: "PUBLIKUM AHNUNGSLOS- FAST EIN SKANDAL (...) Viele waren dem verlockenden Operettentitel auf den Leim gegangen (...) Nlchts da von Wiener Charme und Gemuitlichkeit - nur Schmutz und Armseligkeit"(1). Thirty years after Horváth's death, this reaction by the volce of his target audience, the half-educated Kleinbuirger, Illustrates the effectiveness of his dramaturgy.

1. Hela Boschmann, Bild, Berlin, 24/4/67, p.2. Cited by Hummel, op. cit., p.131f. 